\title{
Productivity Improvement and Corporate Survival: Challenges to Trade Unions
}

\author{
Stephen Talabi Aroge \\ Department of Arts Education \\ Adekunle Ajasin University \\ Akungba Ondo State, Nigeria \\ Tel: +234-703-230-3565Ｅ-mail: draroge@yahoo.com
}

Received: March 31, 2011

Accepted: September 15, 2011 Published: November 21, 2011

doi:10.5430/ijba.v2n4p136

URL: http://dx.doi.org/10.5430/ ijba.v2n4p136

\begin{abstract}
The general perception of workers about productivity improvement is that productivity gains benefit the shareholder and management alone. Very few workers believe productivity improvement benefit the employees. This paper identifies the need to change this perception and speculates that when the perception of workers change towards productivity improvement, the management, unions and government will coexist peaceably in the workplace. It also suggests ways by which training can serve as a response to the challenges for productivity improvement in the workplace in particular and the society in general.
\end{abstract}

Keywords: Productivity Improvement, Trade Unionism, Globalized Economy

\section{Introduction}

Trade Union increasingly wish to be seen as working with employers to create a better and more competitive economy and not as organisations that stand in the way of change and increase costs for firms. They believe that both parties have mutual interests. This had led to more single union agreements (where an employer agrees to deal with only one union) but in return can often expect a no-strike deal from the union (where unions agree never to strike if a dispute cannot be settled).Instead of harming profits, unions increase the wages of about 10 to $15 \%$ of workers by about 10 to $15 \%$ by reducing the wages of the other 85 to $90 \%$ of workers by about $4 \%$. Most economists now think that the wage increases unions can afford their members do not come at the expense of the owners of capital but at the expense of non-unionized workers. As the price of labour increases, the demand for it will decrease. Unions targets of industry protectionism and limits on immigration also have this effect, benefiting unionized workers at the cost of those without union membership.

The effect of union activities to influence pricing is potentially very harmful, making the market system ineffective. By raising the price of labour, above the market rate, deadweight loss is created. Additional non-monetary benefits exacerbate the problem. There can be little doubt that union activities lead to continuous and progressive inflation. More powerful voice when bargaining as a group (e.g. for pay rises) as can threaten industrial action such as strikes, cheaper and quicker to bargain with one trade union representative than individual workers. Workers will have their individual rights better protected e.g. if dismissed unfairly or discriminated against. Workers are better motivated if they feel their interests are being looked after by trade unions. (Hayek, 1960) suggests that union activities lead to continuous and progressive inflation. Another Austrian school economist, Robert Murphy however disputes this by arguing that the increase in the cost of labour simply means that less of other goods can be bought. He writes: If unions succeed in wage hikes, and employers raise the prices, they charge consumers to maintain their own profit margins, and the supply of money remains the same. Then something else has to 'give'. Either the prices of goods and services in no union sectors have to fall and offset the union sector hikes, or people's cash balances need to fall in terms of their purchasing power (Murphy, 2003).

This claim that when labour asks for more wages, the prices of other goods and services fall is not applicable in the Nigerian economy. This is because the economy depends very much on paid employers and government is the greatest employer of labour.

Thus, this paper aims at:

(i) Conceptualizing productivity improvement and corporate survival; 
(ii) Interpreting the concepts of productivity improvement and corporate survival from pluralist' point of view in industrial relations.

\section{Research Questions}

(i.) What is the relationship between productivity improvement and corporate survival?

(ii.) How do pluralists’ interpret productivity improvement and corporate survival?

\section{Methodology}

This paper adopts a qualitative methodology which allows a relation of productivity improvement and corporate survival. It also allows the interpretation of these concepts from the view of pluralism in industrial relations

\section{Productivity Improvement}

Productivity improvement means an increase in output and quality of goods and services in an organization or an industry. Productivity improvement is generally the result of interaction of the factors of production such as capital (equipment and technological capabilities), volume of labour input, quality of labour input and attitude of human resources and scale of operation. The rationale for productivity improvement can be seen from the increasing adoption of the principle of workers' participation in management at enterprise level. Workers' participation can help to set up wage payments and award system that can motivate workers. It also has increasingly preoccupied unions with the process of technological change, the alteration of working rules and institutionalization of changes like safety and retirement issues; promotes higher standard of material well being of citizens; it helps to attain national goals of development. Ideally workers should be aware that workers welfare cannot increase beyond capacity generated by a given industry.

There is an increasing awareness of the social responsibility of workers. Workers are responsible to the consumer apart from its responsibility to the employer. Although, both labour and management concede that there is real gain in the attainment of productivity improvement there are two major areas of disagreement, namely: Job security. When productivity improves through capital intensive approach, labour is the first target of attack; Distribution of the economic benefit of productivity. What proportion of the productivity gains should go to the workers, the firm and consumers?

\section{Corporate Survival in Globalised Economy}

A globalised economy is also known as knowledge economy. The knowledge economy, according to wikipedia, the free encyclopedia (2010), this is a term that refers either to an economy of knowledge focused on the production and management of knowledge in the frame of economic constraints, or to a knowledge-based economy. It is a concept that supports creation of knowledge by organizational employees and helps and encourages them to transfer and better utilize their knowledge that is in line with company/organization goals. The emergence of a global knowledge economy means that globalization now extends beyond markets for goods and finance into markets for technology, knowledge workers, and innovation finance. It has been discovered that there are various interlocking driving forces, which are changing the rules of business and national competitiveness in this $21^{\text {st }}$ Century. These include: Globalization — markets and products are more global. Information technology, which is related to next three: Information/Knowledge Intensity efficient production relies on information and the know-how; over 70 per cent of workers in developed economies are information workers; many factory workers use their heads more than their hands.

New media increases the production and distribution of knowledge which in turn, results in collective intelligence. Existing knowledge becomes much easier to access as a result of networked data-bases which promote online interaction between users and producers. Computer networking and Connectivity - developments such as the Internet bring the "global village" ever nearer. As a result, goods and services can be developed, bought, sold, and in many cases even delivered over electronic networks. This means that survival of the industry can no longer be measured by maintaining production but in terms of adaptation to change, ability of the employee to embrace change in line with knowledge economy and productivity improvement in comparison with other firms in the industry. Moreover, the challenge of the global economy is compelling on the $21^{\text {st }}$ Century organizations that are faced with cut throat competition especially from foreign countries.

The effects of low productivity in Nigerian industries are low patronage of goods and services as well as poor satisfaction and security of jobs. Locally produced goods in Nigerian industries are not enjoying high patronage as it is been done for foreign or imported goods. This is really affecting the input and turn-out of indigenous industries. Many Nigerians, especially the elites prefer buying foreign products (even consumable) at an exorbitant rate, even if the quality is lees to the locally produced one. Nigerian government, in a bid to encourage patronage of the locally produced 
material have put various measures in place so as to enhance optimum performance and productivity of Nigerian industry.

Poor satisfaction and security of jobs is another problem of industrial development in Nigeria. Most of the industries in Nigeria are characterised with poor job satisfaction and security. This is evidenced in the rate at which Nigerian experts are migrating abroad in the name of seeking for greener pastures. Majority of those working in factories and industries where goods are produced were employed casually and being underpaid. Not only that, they were always left to their fate any time there is on-the job accident or hazards.

The level of unemployment is very high in developing nations where the government remains the highest employer of labour. The number of unemployed people is growing steadily as Civil wars, loss of employment and restructuring of societies are creating newly poor groups. The emergence of ICT as the major driving tool in many industries, without doubt, has rendered some workers irrelevant thereby making them to quit. This is really contributing to the low productivity of many Nigerian industries.

\section{Pluralist's View of Productivity Improvement and Corporate Survival}

Pluralism is a view in industrial relations that states that employers and employees in the industry have to co-exist together as partners in progress for the survival of the industry despite their inevitable conflict. This view claims that without the industry, there will not be any relationship between employers and employees in the first instance. More so, if the organization dies, there will be no need to talk about any relationship. Pluralism can be likened to any other human relationships like marriage and community. In all these relations, mutual trust and cooperation are ingredients for survival, progression and development. The point of divergence in organisations is that various agencies in an organisation participate in determining the rules of employment giving room for different loyalties. While organisations have their own rules, trade unions within and outside the organisation also have their own regulations. Whenever there are separate sources of authority, there is the risk of conflict. (Edwards, 2003).

Many organizations especially private corporations dread trade unions because they are seen as troublesome, costly and retrogressive. One of the activities of trade unions that managers hate is strike action which can cause complete closure of industry or low productivity. However, Trade unionism can benefit both employees and employers of labour because trade unions have the moral imperative to make the industry survive in the face of cut throat competition of the global economy and enhance performance on the job in order to increase productivity. The survival of the industry is the major thrust of pluralism in industrial relations.

\section{Conclusion}

For any meaningful and sustainable discussion on productivity, the issues of job security and workers welfare should be discussed. In view of this, industries must find ways of determining the consequences of management decision on their members and take workers' training and education very seriously because it keeps workers on their job, makes them pursue personal goals and makes socially responsible. The issues of productivity go beyond the activities of trade unions. The reality today is that the skills of yesterday may not solve today's problem because of the increasing development of more sophisticated skills in productivity. When machines are available, human beings are less important. Employers and workers need to provide the equipments and update their manpower through training in order to ensure improved productivity. In most developed countries, research is linked with development, but in Nigeria, the two are distant relations. There is little or no data on output per worker and how much a worker does per hour. If all these are measures through research, no employer will want workers to go on strike or be indisposed to work. This means that workers welfare is a necessary condition for improved productivity. 


\section{References}

Armstrong, M. (1991). A Hand book of Personnel Management Practice. London: Kogan Page Ltd.

Armstrong, M. (2006). A Hand book of Human Resource Management Practice. London: Kogan Page Ltd.

Chandan, J. S. (2004). Management Theory and Practice: New Delhi. Vikas Publishing House PVT Ltd.

Fashoyin, T. (1990). Corporate Reward Structure and Organisational Effectiveness. Nigerian Journal of Personnel. Vol. 4. No. 2.

Gomez-Megia, R. et al (1995). Managing Human Resources: New Jersey, U.S.A.: Pronce Hall Inc.

Hayek, F. (1960). The Constitution of Liberty, University of Chicago Press.

http://en.wikipedia.org/wiki/Knowledge_economy

Murphy, R. (2003). Unanticipated Intertemporal Change in Theories of Interest. Unpublished Doctoral Dissertation. New York University.

Otobo, D. (2000). Industrial elations: Theory and Controversies. Lagos: Malthouse Press Ltd.

Otobo, D. \& Omole, M. (1987). Readings in Industrial Relations in Nigeria. Malthouse Publishing Press Limited. 